\title{
correspondence
}

\section{Airey Neave \\ Memorial Trust}

SIR, - Many people have suggested to us that they would like to commemorate the life of Airey Neave, assassinated this year by a bomb in the Palace of Westminster (for obituary see page 433). Some have sent money now banked in a special account.

Since Airey Neave believed in the supreme importance of freedom under the law, we consider that we can achieve something that he would have held dear by creating a Trust to provide for research into the extent of personal freedom under national laws. This may include the provision of travelling scholarships. Candidates will be chosen after they have submitted a short synopsis of the scope of the paper they intend to write. The papers, embodying their research, will be published.

In promoting these studies, priority will be given to applications by candidates from fields in which Airey Neave had a particular interest; former pupils of Radley College or Abingdon School and graduates of Merton College, Oxford; holders of degrees in science or law; members of the legal profession; former prisoners of war; authors; Members or former Members of either House of Parliament.

The value and number of such scholarships will depend upon the amount of money received. Application has been made for the Trust to be registered as a Charity.

Those who wish to be associated with this appeal should send their contributions to The Airey Neave Memorial Trust, c/o The House of Commons, London SW1. Covenant forms will be available on application to the Trust.

$$
\text { Yours faithfully, }
$$

JOHN TILNEY (Chairman) and the committee of the Trust.

London SWI, UK

\section{Costs of toxicity testing}

SIR, - That ICI Ltd is spending $\mathrm{f} 6$ million per annum on its toxicity testing programme seems to underline the fears of smaller companies that the tests they are asked to undertake are too expensive. This is even more the case it we concede that these tests can be but a crude guide to the possible hazards to man. Still, the bankruptcy of a few firms and a reduction in innovation might be a small price to pay for the sensation of safety we all crave; in any case, as the new legislation applies to new chemicals, only the larger more affluent companies with new product developments are likely to be much affected.

Or are they? Mr Langley has suggested (5 July, page 9) that industry ought to be doing more, anyway, under the $1974 \mathrm{Act}$, and the new notification scheme nierely records that defined work has been completed successfully. Is there an implication here that existing chemicals will be subject to the same testing arrangements? The logic of the Act suggests this ought to be so - and recent experience with monomers has thrown doubt on 'long manufacturing experience' as a safeguard on health, making it more likely that some experimental results will be needed.

In this case, the economic impact could be substantial and, because it is happening at a time when another world recession is expected, it could have even more profound effects than usual. It is time to establish some priorities. Let the Health and Safety Executive produce guidelines, not on how to test chemicals, but on how to select chemicals which require to be tested - unless they intend to deal only with new chemicals. Let us concentrate our resources on developing test procedures which effectively screen chemicals for the properties we want to avoid at all costs; and leave lesser hazards until we can afford to attack them. Above all, let us recognise that life is a hazardous and invariably fatal process which will surely survive twentieth century industrialism, if we keep our scientific 'cool'. Yours faithfully,

D. M. CONNING

British Industrial Biological Research Association, Surrey, UK.

\section{Attack on paranormal is unscientific}

SIR, - It is surely profoundly unscientific to claim that "neither electro-magnetism nor any other scientific theory can explain" ESP phenomena as Taylor and Balanovski do (14 June, page 631). The most anyone can ever claim is that existing theories do not explain a phenomenon so far as they can see someone else may be clever enough to find an explanation within existing theories, or to discover a new explanation. The latter possibility is not "ruled out" by the "successful reductionist approach of science," but is probably the main attraction of science to its practitioners. To go on to deduce that an argument of this sort casts any light on whether the phenomenon exists is even more bizarre - would they have argued against the heat of the Sun before relativity and the theory of fusion? Or do they now assume there is doubt that the mu-meson is heavier than the electron because no-one has yet suggested an explanation?

It might be instructive for these authors to study the history of the famous argument over the age of the Earth at the end of the last century. Kelvin had calculated the age from the time taken for cooling; the result was far too short to allow species to have evolved. Biologists suggested Kelvin might have ignored some unknown source of energy, and were roundly mocked by the physicists for being "unscientific". The fact that Kelvin's proponents were both confident and arrogant did not prevent them being wrong - as the subsequent discovery of radio-activity proved.

I might add that I do not believe there is much evidence for ESP, but this is based on the absence of unambiguous experiments rather than on anyone's inability to think of an explanation.

Yours faithfully,

London SW20, UK.

M.WHIPPMAN

\section{West Germany does not pursue Berufsverbote}

SIR, - Your note "German psychologists issue study of Berufsverbote" (31 May, page 363 ) is utterly misleading. The West German government does not pursue a policy of Berufsverbote. Nobody is banned here by the government to enter any profession of his choice. The federal and state governments reserve the right to select those who apply for employment as civil servants, a status that provides life-long job security. I cannot see anything illiberal when the federal and state governments reject civil service status to a handful of totalitarian radicals. To proceed differently would endanger the liberal system in any western democracy. In my opinion, the slogan Berufsverbote is an infamous lie, cleverly invented by leftist totalitarians to discriminate against the most liberal political system that has ever evolved in the rather sad course of German history.

$$
\text { Yours faithfully, }
$$

University of Munich, West Germany.

\section{Degree-day values}

SIR, - In a recent issue of Nature (14 June, page 565 ) the potential value of the 'degreedays' measure was indicated. Readers who wish to obtain degree-day values for the UK may be interested to know that such information is available in Energy

Management, published by the Department of Energy; and is also reproduced in Energy

Digest, published by Allens (Clerkenwell) Ltd.

Degree-day users requiring early figures may obtain these from the EQAS service (Freefone 3140 , or 8305 in Scotland). Detailed information is available in the free booklet Degree Days, available from: Library,

Department of Energy, Thames House South, Millbank, London SW1P 4QJ. Yours faithfully,

Newport Pagnell, Buckinghamshire, UK.

\section{The caddish salamander}

SIR, - The vocabulary available to sociobiologists includes altruism, nepotism, selfishness and spite, but is still incomplete. Arnold (Z. Tierpsychol.42, 247; 1976) describes how a male salamander (Amblystoma) may intrude between the members of a mating pair, imitate the female, and induce the rival male to release a spermatophore which is then covered with the intruder's own sperm; the latter achieve fertilisation. For this I propose the term caddish behaviour.

\section{Yours faithfully,}

S.A. BARNETT

Australian National University,

Canberra, Australia.

\section{Erratum}

In the issue of Nature of 21/28 December, page 754 , in a letter by Drs Karlson and Dixon on biochemical nomenclature, the word 'bisphosphate' was twice misprinted as biphosphate in the last two lines of the third paragraph. The authors were pointing out the distinction between 'diphosphate', indicating a single diphosphate group in ADP, and 'bisphosphate', indicating two separate substitutions - as in fructose 1,6-

bisphosphate. 